\title{
Melida Travančić
}

\section{TIJELO I IDENTITET U STVARALAŠTVU SENKE MARIĆ}

Senka Marić knjigom poezije Do smrti naredne i romanom Kintsugi tijela fokus stavlja na tijelo, odnosno na analizu i tumačenje promjena na tijelu uzrokovanih bolešću. Cilj ovog rada jeste potvrditi pretpostavku da tijelo može uvjetovati identitet te prikazati na koji se način to ostvaruje u opusu Senke Marić. Posrijedi su promjene koje se dešavaju u ženi i načinu na koji se one manifestiraju na svijet oko nje te kako promjene na tijelu uslovljavaju sve ostale "životne uloge" žene i kako je tijelo najbolji pokazatelj (samo) identifikacije. Posebna pažnja u radu posvećuje se načinu na koji se bolest odražava na tijelo, na ono što žena (prije i poslije) jeste. Tijelo je jedan dio identiteta i na njemu se često i fizički odražavaju sva preživljena iskustva i sve situacije kojima smo izloženi.

Ključne riječi: Senka Marić, identitet, tijelo, bolest, smrt, autopoetika, poezija

\section{UVOD}

Posljednjih nekoliko godina na bosanskohercegovačkoj književnoj sceni javili su se snažni glasovi književnica koje na drugačije načine govore o pojedinim temama o kojima se do sada nije ili se govorilo jako malo. Jedna od tih tema je i tijelo i način na koji ga bolest mijenja (da ne kažemo - uništava), odnosno kako mijenja ženu i ono što ona jeste. Posredstvom književnosti autorice pokušavaju odgovoriti na pitanje da li (i u kojoj mjeri) promjene na tijelu (uzrokovane bolešću) predstavljaju teret ženi i da li su one prepreka za neometan doživljaj sebe i Svijeta oko sebe? Pored problema svakodnevnice i društva u kojem žena živi i radi (ili barem pokušava živjeti) postavljeno je i pitanje traume, bola i tijela posredstvom kojeg ona otkriva i prikazuje svoj identitet. O tijelu, suočavanju s bolesti, o borbi s karcinomom i promjeni identiteta uslovljenog promjenama na tijelu 
otvoreno (i hrabro) govori Senka Marić prvo knjigom pjesama Do smri naredne, a zatim i romanom Kintsugi tijela ${ }^{1}$, za koji možemo kazati da se na neki način oslanja i izrasta iz njene knjige poezije. Selma Raljević naglašava da su, "iako zasebne i nezavisne", ove dvije knjige "fragmenti jedne historije, odlomljeni dijelovi jednog tijela, književnoumjetnički eksperimenti pisanja tijelom i pisanja sebe Senke Marić.” (Reljević, 2019, str. 286) U knjizi poezije Do smrti naredne govori se o ženi, tijelu i oblikovanju njenog identiteta, ali za ovaj su rad posebno značajne četiri pjesme iz prvog ciklusa Je li se ovako umire?, a govore o suočavanju (prihvatanju) i borbi s bolesti, te načinu na koji bolest preoblikuje tijelo i u kojoj se mjeri posredstvom tijela oblikuje identitet. Dok je u kratkom romanu Kintsugi tijela situacija nešto drugačija jer je narativni tok i pripovijedanje neuobičajeno; naime, radnja romana ispričana je u drugom licu. Pripovijedanje u prvom licu često je previše sugestivno, pa je skoro uvijek na granici, posebno kada je riječ o ovoj temi, da preraste u patetiku, dok je treće lice umnogome distancirano i ne bi bilo uvjerljivo. I knjiga poezije i roman imaju skoro identično polazište: odlazak partnera, završetak ljubavi i otkriće karcinoma dojke (u romanu prvo bol u ramenu stvaranjem šiljastih naslaga kalcija, zatim i opipavanjem kvržice na dojci). "Priča" Senke Marić je proširena i zaokružena u jednom univerzalnom značenju šta znači biti žena i postojati danas u svijetu, šta znači transformacija tijela (od djevojčice u ženu), kakve su promjene uzrokovane kako odrastanjem tako i bolešću, jer u oba slučaja tijelo se mijenja. Tijelo jeste vanjska oznaka uz koju se veže bol, trauma, strah i smrt, i u tom kontekstu u njenom stvaralaštvu nema poze i sve se odvija između bića i svijeta. Za nju književnost predstavlja put k višem saznanju, jer ona stvarnost i odnos bića spram nje shvata, razumije, prihvata lucidno i bez obmane. Književnost nije obmana, ona je čista $\mathrm{i}$ uzvišena potreba za progovaranjem, za istinitijom ljudskom komunikacijom koju autor/ica ostvaruje s čitateljem. Marić pisanjem prikazuje vezu sa svijetom, ona ga osluškuje, bilježi, iskorištava dijelove tog svijeta, detalje koji je okružuju, kao i elemente stvarnosti. Na taj način detektira i putem pjesničkog i narativnog diskursa prenosi bol i govori o drami bića. Iz ciklusa u ciklus (kada je riječ o poeziji) ili iz stranice u stranicu romana, čitatelj

\footnotetext{
${ }^{1}$ Za roman Kintsugi tijela Senka Marić dobila je 2018. godine u Tuzli nagradu Meša Selimović koja se dodjeljuje autorima iz Bosne i Hercegovine, Srbije, Hrvatske i Crne Gore za najbolji roman.
} 
nailazi na svakodnevne situacije i osjećaje što ih svako od nas doživljava ili ih može doživjeti.

\section{TIJELO ILI O IDENTITETU}

Žensko pismo, identitet i tijelo ${ }^{2}$ nužni su pojmovi pri proučavanju teorije ženskih žanrova. I danas se žensko pismo koristi kao naziv za autorice koje se bave "ženskim" temama. ${ }^{3}$ A onda se nameće pitanje kakve su to ženske, kakve muške teme? Je li ih moguće podijeliti? Na koncu, i Hélène Cixous smatra da termin žensko pismo nije moguće definirati, već da praksa ženskog pisanja izmiče teoriji i dekodiranju. Ono ne pripada isključivo i samo ženama već ga mogu pisati i muškarci i žene. ${ }^{4}$ Na njeno tumačenje oslanja se i Andrea Zlatar navodeći da je "ženski tekst nespoznatljiv, kao što je i tijelo nespoznatljivo jer prelazi granicu stvarnoga i dopuštenoga" (Zlatar 2004, str. 66). Zlatar dalje navodi da se žensko pisanje često određuje spram toga što žene ne pripadaju vladajućem diskursu (kojeg su opet oblikovali muškarci), ali, kako ga žene nisu oblikovale, tako nisu ni ovisne o njemu, dok Luce Irigaray poziva na preispitivanje koncepta muškog i ženskog tijela kao ograničavajućih faktora. ${ }^{5}$

\footnotetext{
${ }^{2}$ Ne tako daleko u prošlosti tijelo se pokušavalo zanemariti ili staviti u poziciju podređenosti. Jednostavno, sve vezano za tijelo i tjelesnost ostavljano je u drugi plan. Promjene se dešavaju u savremenom (post)modernom društvu u smislu da se ono, uvjetno kazano, oživi, te se mu se posvećuje posebna pažnja kao jednom od najznačajnijih elemenata za objašnjavanje identiteta.

${ }^{3}$ Termin žensko pismo (fra. écriture féminine) u književnost uvodi francuska feministica i filozofkinja Hélène Cixous. Ona u eseju "Smijeh meduze” objavljenom 1975. naglašava da bi trebalo "da žena piše o ženi i da privede ženu pismu, od koga su, na isti način kao i od svojih tela, one nasilno udaljene; iz istih pobuda, na osnovu istog zakona, sa istim smrtnim ciljem." (Cixous, 2010, str. 19) Možemo kazati da je žensko pismo nastalo iz potrebe da se ženama, njihovom iskustvu i tijelu da glas, da one postanu ravnopravne članice društva.

${ }^{4} \mathrm{U}$ svojoj je teoriji Cixous napomenula da žensko pismo ne moraju pisati samo žene, mada se najčešće termin “ženska književnosti” koristi kao sinonim ženskog pisma. To ne treba smatrati greškom, jer se rijetko pojavi književnik koji piše o iskustvu žena. I danas se odrednica žensko pismo koristi kada se posebno želi naglasiti da se u tekst upisuje specifično žensko iskustvo, mada se naglašava da ono nije određeno spolom autora i da žensko pismo ne određuje žanr ili stil, nego sadržaj koji je isključivo vezan za tvorbu ženskog identiteta, žensko (tjelesno) iskustvo, te posmatranju žene u društvenom i kulturnom kontekstu.

${ }^{5}$ Luce Irigaray uvodi pojam parler femme što znači žena koja govori, ali to u ovom slučaju ne razumijevamo samo kao ženski govor, nego je iz zalaganja kroz njen rad vidljivo
} 
Kada posmatramo femnističku kritiku i definiranje ženskog pisma, onda treba kazati da u tom kontekstu postoje dvije struje. Sa jedne strane je francuska feministička kritika, dok je, sa druge strane angloamerička; obje pažnju posvećuju posebnostima ženskog pisanja, ali njihova polazišta se umnogome razlikuju. Francuska se kritika, kako smo vidjeli, usmjerava na falocentričnost jezika kao ploda muške dominacije. Žensko se pismo shvaća kao nešto što ne određuje spol autora, nego su važni samo tema i stil djela. Angloameričku kritiku žensko pismo zanima sa socijalnog gledišta te društveno konstruirane ženske rodne uloge, tako da se u fokus posmatranja postavlja reprezentacija žena u književnim tekstovima, kao i perspektiva čitateljica. Jasmina Lukić navodi da je "ova vrsta kritike, ideološki jasno angažovana u svojoj feminističkoj kritici patrijarhata, imala je nesumnjivih metodoloških ograničenja, što je navelo feminističke kritičarke da se pozabave pitanjima metoda i da pokušaju jasnije da definišu specifično područje svojih istraživanja. Tako se javlja grupa feminističkih teoretičarki koje smatraju kako je njihov primarni zadatak proučavanje ženskog stvaralaštva i potraga za specifičnim odlikama ženskog pisanja. Elaine Showalter uvodi pojam 'ginokritika', koji upućuje na usmerenost ove kritike na žene i žensko stvaralaštvo. Reč je o jednoj vrsti 'konstitutivnog gesta' kojim feministička kritika dokazuje da ima svoj poseban predmet i metod istraživanja - što je kao situacija analogno zbivanjima u književnoj teoriji glavnog toka u vreme dominacije formalnih metoda, kada se težilo jasnijoj definiciji predmeta izučavanja književne teorije i određivanju differentia specifica književnog teksta." (Lukić, 2010) Elaine Showalter pod osnovni predmet istraživanja ginokritike postavlja žensko pisanje u nadi da će se otvoriti prostor za novu metodologiju čitanja tekstova autorica. Lukić dalje navodi da teorijska pozicija Showalter "ostaje duboko ambivalentna, jer ona sama ostaje primarno sociološki usmerena i zalaže se za promociju koncepta ‘ženske kulture’ kao specifične potkultu-

da ona nastoji oblikovati posebno mjesto za žene kao druge/o, kao što podrazumijeva drugačiji način ostvarivanja žene i muškarca kroz jezik/pisanje.

${ }^{6}$ Tekst Jasmine Lukić “Žensko pismo i žensko pisanje u devedesetim godinama” u kojem autorica donosi pregled razvoja ženskog pisma, uključujući djela najznačajnijih feminističkih teoretičarki sve do devedesetih godina u kojima predstavlja radove najznačanjih južnoslavenskih feministica, te analitičkim pristupom u središte istraživanja postavlja neke od najznačajnijih knjiga žena devedesetih godina. Tekst je objavljen u Sarajevskim sveskama 2010. godine, br. 2. Dostupan na: https://www.sveske.ba/en/content/ zensko-pisanje-i-zensko-pismo-u-devedesetim-godinama. 
re koja postoji u svakom patrijarhalnom društvu i koja se samo delimično preklapa sa muškom kulturom glavnog toka.” (Lukić, 2010) Kada govorimo o ženskom pismu i njegovim odrednicama od strane feminističke kritike sedamdesetih i osamdesetih godina 20. stoljeća, ono se definira kao upisivanje ženskog tijela i drugosti žene u jezik i tekst (Showalter). Za žensko se pismo danas koristi još i pojam feminilni i feministički tekst, a i jedan i drugi obuhvataju tekstove napisane sa ženskog iskustva, samo feministički tekst ima jasno određenu kulturnu poziciju. Žensko je pismo zapravo jezik ženskog iskustva koji se umnogome naslanja na iskustvo tijela, odnosno načina na koji se tijelo upisuje u tekst i nastojanju da se ono artikulira iznutra, posredstvom unutrašnjeg doživljaja tijela. 'L'écriture féminine je način pisanja koji afirmira prisnu povezanost žene s njenim tijelom i koji negira ono shvaćanje po kojem je pisanje isključivo aktivnost duha i kao takvo rezervirano za muškarce.” (Lešić, 2006, str. 443)

U kontekstu u kojem govorimo o ženskom pismu, važno je navesti tri faze njegovog razvoja: Prvo je faza "imitacije prevladavajućih načina pisanja dominantne tradicije i pounutrenje njezinih standarda umjetnosti i pogleda na društvene uloge." Druga je faza pobuna "protiv tih standarda i vrijednosti te zastupanje manjinskih prava i vrijednosti, zahtjev za autonomijom." Dok je treća faza ona koja nas najviše i zanima i koja i danas traje, a to je faza samootkrića, "okretanje prema unutra, potraga za identitetom." (Moi, 2007, str. 84) Žensko pismo, pisanje nadovezuje se na razumijevanje identiteta, a ono što je nama u ovom radu najznačajnije je pokazati kako i u kojoj mjeri je tijelo žene i promjene koje se na/u njemu dešavaju značajno pri oblikovanju identiteta. Tijelo se konstantno mijenja (proces starenja), ali se mijenja i pod utjecajem bolesti, kao što se mijenja i odrastanjem. Prema Elizabeth Grosz, tjelesnost i tijelo su kao aspekt identiteta i ljudske egzistencije umnogome bili zanemarivani u filozofiji zapadnjačke humanističke tradicije, i danas je "tijelo u konceptualnom smislu još uvijek slijepa pjega u razmišljanjima ne samo glavnih struja zapadne filozofije nego i suvremene feminističke teorije. Feminizam je nekritički preuzeo mnoge filozofske pretpostavke o ulozi tijela u društvenom, političkom, kulturnom, psihičkom i seksualnom životu te se, barem u tom smislu, može smatrati suučenikom rhizoginije karakteristične za zapadni način razmišljanja." (Grosz, 2002, str. 6) Navodeći dalje da se reprezentacija muškarca povezuje s umom, a žene s tijelom, tako što se: “Ženstvenost tipično prikazuje 
(bilo eksplicitno ili implicitno) na jedan od dvaju načina u ovom križnom sparivanju opozicija: ili se um nudi kao ekvivalent muškosti, a tijelo kao ekvivalent ženskosti (i tako a priori isključuje žene kao moguće subjekte znanja ili filozofe) ili se svakom spolu pridaje njegova vlastita forma tjelesnosti." (Grosz, 2002, str. 16) Tako društvo umnogome zanemaruje činjenicu da se tijelo mora razumjeti kroz spektar različitih identiteta. Prema njenim navodima, odnos prema tijelu na Zapadu je određen dualizmom duh - tijelo. Duh je prikazat kao onaj dio koji kontrolira tijelo, dok je tijelo označeno kao manje vrijedno i shvaćeno je površno i pasivno. Za razliku od ranijih shvatanja, definiranja i odnosa prema tijelu, današnje (post)moderno vrijeme u kojem živimo sve je više okupirano tijelom i tjelesnošću, te se neprestano u fokus postavlja novi (umnogome drugačiji) doživljaj i odnos prema vlastitom tijelu. Više nema tako jasno određenog dualizma, već istraživanja ukazuju na neodvojivu povezanost duha i tijela, odnosno tjelesnog i materijalnog aspekta. Stoga je danas pitanje odnosa tijela i identiteta jedno od značajnih pitanja za razumijevanje tjelesnosti u savremenoj kulturi. Nemoguće je govoriti o tijelu, a zanemariti identitetsku, ali i kulturnu, simboličku, i religijsku dimenziju - sve su to elementi koji nas čine različitim u odnosu na druge. Tijelo jeste osnovna okosnica osobne identifikacije i kroz njega se konstruira jastvo. (Kos, 2011, str. 224) Marina Biti naglašava da je tijelo temelj identiteta; ono je "pozadinski autor u nama upisane slike svijeta, i predstavlja onaj faktor od kojega nikada - ma kako ga minimizirali, racionalizirali ili čak i izravno negirali - ne možemo pobjeći, koji dopire do značenja koja uspostavljamo iz sfere nesvjesnog koju nastanjuje, one koju smo najmanje sposobni podvrgavati kontroli, a potpuno nesposobni do kraja poništiti." (Biti, 2008, str. 310)

U ovom radu nastojimo objasniti povezanost identiteta i tijela, i pokazati na koje načine žensko tijelo postaje nositelj identiteta te kako unutrašnji i vanjski faktori preuzimaju kontrolu nad tijelom. Da bismo razumjeli kako i u kojoj mjeri tijelo (i promjene na tijelu) može oblikovati identitet moramo ga najprije definirati. Slijedeći logiku pri definiranju identiteta, trebali bismo odmah s početka postaviti pitanje: Ko sam ja?, odnosno: Ko smo mi? Odgovoriti na ovo pitanje nije nimalo jednostavno, jer nam se odmah nameće i drugo pitanje: Je li mi baš uvijek znamo ko smo? Suzana Kos u tekstu u kojem se bavi ženom, ideologijom i tijelom u feminističkoj poetici Alexsandre Berkove navodi da: "U suvremenim raspravama o identitetu 
afirmirale su se dvije dominantne struje - esencijalistička i konstruktivistička. Prva struja shvaća identitet kao zadanost, on je jedan i postojan, imanentan subjektu i nepromjenljiv. Druga struja percipira identitet, a time i tijelo, kao rezultat djelovanja kulturnih i društvenih praksi. Takav je identitet modularan i subjekt sam ima malo utjecaja na njegovu konstrukciju. (Kos, 2012, str. 222)

Interdisciplinarna istraživanja pokazuju da je identitet nestabilna konstrukcija nastala pod utjecajem društva. "Identitet nije fiksna, čvrsta tačka iz koje polazimo i kojoj se vraćamo, identitet je kontinuirani proces, proces stvaranja i razaranja, napuštanja stvarnog i uspostavljanja novog. Identitet se stvara u procesu razlikovanja, stalnoga uspostavljanja identiteta sebe u odnosu na druge, jastva u odnosu na druga jastva kao i na prepoznatu drugost u vlastitom ja." (Zlatar, 2004, str. 21) Kada govori o identitetu i načinu/ima njegovog oblikovanja, u knjizi Književna teorija Jonathan Culler postavlja osnovno pitanje da li je jastvo nešto dato ili nešto proizvedeno i treba li ga promatrati kroz društvo ili kroz pojedinca? Na osnovu ovog pitanja, on razvija “četiri osnovne niti moderne misli o tvorbi identiteta" (Culler 2001, str. 127). Prva govori o pojedincu kao jedinstvenom biću, druga naglašava da je svaki pojedinac određen svojim porijeklom i društvenim značenjima. Treća nit spaja pojedinca i proizvedeno te naglašava promjenljivu prirodu jastva koje postaje ono što jeste, dok četvrta, posljednja, nit koja govori o tvorbi identiteta, pojedinca posmatra kao spoj društvenog i proizvedenog, odnosno "pojedinac se utemeljuje kroz različite subjektne položaje koje zauzima” (Culler 2001, str. 127).

Stoga, da li je identitet nešto što se lako mijenja? Ili je on stalna kategorija? Tokom života imamo više uloga i one nisu statične, nego promjenljive kategorije jer: "Identitet nije jedan, nitko nema samo jedan identitet, iako je svaki čovjek identičan jedino samome sebi. (...) Naš je samoidentitet izgrađen od mnoštva identiteta - rodnog, klasnog, socijalnog, intelektualnog, političkog, lokalnog, regionalnog, etničkog... - i svi oni postoje jedan pored drugoga, jedni ukriženi s drugima.” (Zlatar, 2004, str. 15)

Nas u o ovom kontekstu posebno zanima na koji se način identitet povezuje s tijelom i pisanjem žena. U književnom djelu Senke Marić je to žena i promjene koje se događaju na tijelu (promjena vizuelnog identiteta), koje mogu, ali ne nužno, ostaviti psihičke posljedice. I nije riječ ni o kakvom 
specifičnom ženskom identitetu (Luce Irrigaray); posrijedi je tekst o onome što je pre/proživljeno (u potpunosti lično iskustvo) ${ }^{7}$ koje književnicu dovodi izvan granica zadatih društvenih normi. Ona ima svijest o vlastitom iskazu i poznavanju (i detekcijom) slojeva vlastitog identiteta, jer "identitet se oblikuje kroz postupak autorefleksije, odnosno samotumačenja" (Zlatar, 2004, str. 26). Senku Marić ne konstruira vlastiti život; ona ga rekonstruira, na taj su način procesi autorefleksije najvidljiviji - u njima se "samooblikovanje identiteta događa u procesu pisanja, a tekst postaje prostorom oblikovanja identiteta"8. (Zlatar, 2004, str. 26)

\section{BOLEST: TIJELO OTRGNUTO OD SMRTI}

Uvesti čitatelja u vlastiti prostor, progovoriti o nadi i putu za spas, znači suočiti se s traumom, osjetiti blizinu smrti. U fokusu knjiga Senke Marić, u njihovom prvom planu je žena, odnosno zrela žena u vlastitom svijetu koji se mijenja i pomjera otkrićem kvržice na dojci, odnosno suočavanje

\footnotetext{
${ }^{7}$ Uključivanje autobiografskih podataka u djelo nije nikakva novina (jer kada govorimo posebno o poeziji, zapitamo se šta je ona drugo do sam pjesnik!). Književna teorija nas uči da značenje djela ne bismo trebali tražiti preko autora, ali, sa druge strane, književnici mogu (i često to i rade) raznim literarnim tehnikama fikcionalizirati svoje živote. Književnica, u ovom slučaju, ne fikcionalizira; ona otvoreno govori o sebi, uključuje detalje iz vlastitog života, ali postoji viša istina od one biografske i djelo Senke Marić ne možemo čitati samo na taj način, tragajući za onim što je stvarno, a šta izmaštano to bi bio u potpunosti pogrešan pristup. Senka Marić navodi da je možda olakšavajuća okolnost što ona daje "književnosti prednost nad stvarnim životom. I kada koristim lično iskustvo, kao u ovom romanu, zanimaju me potrebe teksta, šta on može da primi, šta može da podnese, šta se iz tog iskustvenog materijala može iskoristiti u tekstu. Materijal se prilagođava potrebama odabrane forme i nastaje svijet koji, koliko god da jeste ili nije zasnovan na stvarnosti, im ili barem pokušava imati svoju cjelovitost, samodovoljnost, uvjerljivost. U romanu Kintsugi tijela, veći dio teksta jeste zasnovan na onome što sam proživjela, ali za sam roman to je sasvim nebitno. Važno je da li on u književnom smislu funkcioniše kao istina. Ljudi me često pitaju koliko je od svega toga istina. Ne postoji odgovor na to pitanje. Sve je istina, i ništa nije. Književnost i život postoje na različitim kolosijecima, mogu se preklapati, ali nikada ne mogu biti isto." (Marić, 2019)

${ }^{8}$ Vidjeti više u: Andrea Zlatar: Tekst, tijelo, trauma, u poglavlju "Identitet, javstvo, tekst" u kojem autorica govori o personalnom identitetu koji, prema njenim riječima, nije "neprekinuti slijed objektivnih činjenica, nego kontinuirani slijed samointrepretacije.” (str. 26) U tom kontekstu, za ovaj je rad izuzetno značajno razgraničiti procese samorazumijevanja i samotumačenja (autobiografskog i književnog) kod Senke Marić, jer čitatelj ostaje nesiguran da li je riječ o "konstrukciji ili rekonstrukciji vlastitog života kroz priču”. (Zlatar, 2004, str. 26)
} 
s bolesti koja je spremna agresivno otkidati dio po dio tijela. Otkrivanje drugačijeg oblika postojanja sebe i prihvatanja tijela koje se mijenja razvojem bolesti Senka Marić prikazuje posredstvom poetskog i narativnog diskursa, a svakom novom pjesmom i stranicom romana sve dublje ulazi u samoanalizu i samotumačenje.

Kada govorimo o knjizi poezije, nije samo prvi ciklus Je li se ovako umire? i nisu samo četiri pjesme u njemu ("Smrti", "Post-op", "Hronika jedne bolesti", "Tijelo ovo") one koje na direktan način govore o bolesti, nego i ostale pjesme (kao one o nestanku ljubavi, a u čijem je fokusu također tijelo) pokazuju iskorak iz intimnog u književni diskurs, fokusirajući se na trošnost i izdržljivost tijela. Pisanje o sebi i svom životu važno je za oblikovanje ja u tekstu u kojem iznosi privatno i intimno iskustvo. ${ }^{9}$

Prvo je posrijedi šok uzrokovan otkrićem bolesti, zatim bol i gašenje dosadašnjeg života žene koja govori o strahovima, snažno pri tom ponirući u sebe i neprestano pomjerajući granice izdržljivosti. Iskustvo koje drugi nisu imali, bol koju nisu osjetili, ona prenosi putem književnosti i približava čitatelju. U stvaralaštvu Senke Marić govori se o sveprisutnom osjećaju smrti kao i prikazivanju ne samo promjene na tijelu i vanjskim ožiljcima, nego i onim unutrašnjim koji se nose još od djetinjstva (npr. drugi dio radnje romana Kintsugi tijela). Riječ je o tijelu žene izloženom često i nepodnošljivom bolu koje oduzima mogućnost pomjeranja i razmišljanja. Tijelo je ovdje dato kao objekat posmatranja, i to ne pred drugima, nego pred sobom, tako, npr., u romanu protagonistkinja spoznaje sebe i o tome glasno govori, čime gubi pravo na svoj intimni prostor, a svijest o tijelu pojačava spoznaja o bolesti, kasnije i odstranjivanje njegovih dijelova. Ženski identitet ne određuje samo tijelo, nego žensko iskustvo tijela. Tijelo kao vanjskost, vanjski dio identiteta, pamti sve promjene izvana i neprestano je izloženo, ili je u opasnosti da bude, fizičkoj boli. Također, tijelo je nemoguće sakriti, sačuvati od bolesti, a to je pokazatelj i da ga je nemoguće kontrolirati. U knjigama Senke Marić uočavamo kako oboljenje

\footnotetext{
${ }^{9} \mathrm{U}$ ovom slučaju ne ispitujemo relacije između autorice i literarnog ja (ispitivanje vjerodostojnosti), nego se želi govoriti o biografskoj autoreferencijalnosti, kako je po vrsti autometateksta dijeli Dubravka Oraić Tolić. U slučaju poezije teško da možemo govoriti o autobiografskom u klasičnom razumijevanju tog pojma. On nije uobičajen za poeziju, ali ono što je ovdje nedvojbeno posrijedi jeste referencija na vlastiti život $\mathrm{i}$ ispisivanje onoga što se doživjelo (i preživjelo), kao što je Senka Marić bila suočena s karcinomom dojke.
} 
od karcinoma dovodi do tjelesnih promjena, ali su ove knjige i svojevrsni zapis o tome šta se događa s tijelom i time kako ono izgleda nakon bolesti. Tragovi koje ostavlja bolest su vidljivi i promjenom tijela dolazi se i do promjene identitetske (samo)percepcije.

Kada govorimo o knjizi poezije Do smrti naredne od prvog ciklusa u kojem je posrijedi suočavanje sa sobom, sa (mogućnosti) smrti, strahom od njene blizine, sve do posljednjeg, koji se završava pjesmom "Dobro je", traje potraga, implicitno ili eksplicitno, za spasom, odnosno vjerom, nadom i željom u spas (ne samo od bolesti!), za još jednom prilikom da se živi, kao što se govori o tijelu i načinu na koje ono pokazuje (promjene) identiteta, jer žena nije ista prije i nakon saznanja da je bolesna, kao i prije i poslije bolesti, i da je smrt jedan od mogućih ishoda. Stoga je i prva pjesma "Smrti" ulazak u intimni prostor lirske subjekte i jedna od najpotresnijih u knjizi.

Otići ću u planinu

I rukama čupat ću livadsko bilje

- tu je negdje sigurno, rekli su,

i ona što rak liječi -

Oko mene zvečat će zmije

ljute i rasiktane (...)

(Marić, 2016, str. 7)

Nakon niza slika koje će se sve desiti između lirske subjekte i prirode, zapitanosti nad mogućim spasom (biljkom kao lijekom) i potpunom bespomoćnosto, događa se zaokret u pjesničku nutrinu i pitanje: "Smrću mojom hoće li umrijeti svijet?" (Marić, 2016, str. 7-8.) Na ovaj se način poetski uspjelo artikulira praznina bića, jer je posrijedi pjesnička opservacija o tišini, o praznom prostoru u koji ulazi žena nakon otkrića bolesti. ${ }^{10}$ Bogate, originalne poetske slike i kompleksna značenja odlikuju ne samo navedenu pjesmu i prve rečenice romana, nego sve pjesme iz ove zbirke i sve stranice romana - kao što nam kazuju da pisanje ne mijenja svijet, niti liječi bolest, ali donosi utjehu i nadu - prikazuju hrabrost i odlučnost žene da ne umre (mnogo puta naglašeno u romanu), a onda i da je sve ipak podnošljivo (i odlazak muškarca i suočavanje s bolesti). Ovo su knjige koje govore o

\footnotetext{
${ }^{10}$ Tako počinje i roman: detektiraju se godine u kojima se događa niz loših stvari za protagonistkinju: suprug je napušta, pojavljuje se bol u ramenu izazvana kalcifikatom i, na koncu, otkriće kvržice na dojci kao jedan od najtežih trenutaka koji potiskuje sve druge bolove.
} 
temi/ama o kojima se rijetko ili nikako ne kazuje u bosanskohercegovačkoj književnosti, posebno iz ženske vizure: otkrivanje bolesti, suočavanje s njom i njenom agresijom da "pojede" tijelo, dok je, sa druge strane, ovo književnost koja svjedoči o jačini ljudskog duha, njegove nesalomljivosti i snazi želje da se iz te bitke izađe kao pobjednik - jer bolest nije samo stvar pojedinca i njegovog intimnog prostora; bolestan je čovjek u socijalnom smislu stigmatiziran od strane društva.

Bolest i integrira iznutra "kada ja prisilno biva odvojeno od drugih, bolest ga na zaseban i zastrašujući način integrira. Čovjek postaje različitim od onog kakav je bio prije, a bolest ispunjava cijeli prostor jastva." ${ }^{11}$ (Zlatar, 2004, str. 103-104) Kakve su promjene na tijelu i na koji se način lirska subjekta pokušava svime nositi, ostati snažna i nasmijana, najbolje svjedoči pjesma nakon operacije i hirurškog otklanjanja dojke, naslovljena "Post-op”. Prije svega, ovdje je riječ o suočavanju lirske subjekte sa sobom, svojim "novim" (izrezanim) tijelom, o nastojanju da sebe takvu prepozna, i, najvažnije, da sebe takvu prihvati.

Dugačak je petnaestak centimetara

Uštopan plavim koncem

Liči na ogromnu mršavu gusjenicu

zalutalu na mome tijelu (...)

Koža oko njega

blago se rumeni

bolna na dodir

zateže pri pokretu ruke

Uradili ste odličan posao!

kažem doktoru dok zabija veliku iglu

u moje meso

izvlačeći nakupljenu limfu

Gotovo se i ne primijeti da mi nedostaje

trećina sise

smiješimo se zadovoljno

\footnotetext{
${ }^{11}$ U knjizi Tekst, tijelo, trauma, u poglavlju naslovljenom "Tijelo: modus komunikacije" Andrea Zlatar govori o romanima Slavenke Drakulić u kojima važno i značajno mjesto zauzima pitanje tijela i identiteta. U dijelu teksta naslovljenom "Retrospekcija kao introspekcija" Zlatar posebnu pažnju posvećuje tumačenju romana Slavenke Drakulić Hologrami straha u kojem ključno mjesto zauzima govor o bolesti koja junakinju izolira od drugih ljudi, što prepoznajemo i u knjigama Senke Marić.
} 
i on

i ja

(Marić, 2016, str. 9)

Dok u romanu stoji:

Ovo je priča o tijelu. Njegovoj borbi da se osjeti cjelovitim dok ga stvarnost rastavlja na fragmente. Rez ide od desne bradavice prema leđima, pet centimetara udesno pravi laganu krivinu i nastavlja do pazuha. Još je svjež i crven. Nisi odstranio tako puno, govoriš hirurgu. Ponosno klima glavom. Uradio je dobar posao. Zategnuo dojku odozgo pa se ne vidi koliko fali. Smiješite se zadovoljno.

(Marić, 2019, str. 21)

Ovo je priča o tijelu, priča o gubljenju njegovih dijelova (hirurškim intervencijama), riječ je o vanjskom i unutrašnjem bolu, govor o krhkosti i lomljivosti tijela, ali i opraštanje lirske subjekte i protagonistkinje romana od sebe kakvu poznaje i nastojanje da se prihvati jedna nova, drugačija ja. U stvaralaštvu Senke Marić riječ je o konstrukciji ženskog identiteta posredstvom tijela, prihvatanja na koji se način tijelo mijenja (vanjski faktor) i kako te promjene djeluju na formiranje identiteta, ali i osvještavanje kulturnih obrazaca koji oblikuju ženskost.

U prvom ciklusu knjige poezije, kao i prvom dijelu romana ${ }^{12}$ radnja teče od otkrivanja karcinoma, suočavanja s njim, do nastojanja da se prebrodi bo-

\footnotetext{
${ }^{12}$ U romanu Kintsugi tijela Selma Raljević izdvaja dva toka radnje i nekoliko njenih podtokova, a "glavni tok radnje romana bavi se životnim iskustvom kintsugija ženskog tijela oboljelog od karcinoma dojke, gdje je glavna junakinja, čijim tijelom Senka Marić ispisuje sebe, ona čije je tijelo polomljeno i koje se, kao tečnim zlatom ili platinom, popravlja kemoterapijom i drugim tečnim otrovima koji liječe. Paralelno tome toku radnje $i$, istovremeno, unutar njega, odvija se i razvija podtok radnje, relativno na principu asocijativnih sjećanja glavne junakinje, koja na početku vremena 'sadašnjeg' priče ima četrdeset i dvije godine. Naime, roman se ostvaruje u unutrašnjem vremenu vječne sadašnjosti, kako bi to rekao Vilijam Fokner (William Faulkner), mada ima i vanjski vremenski okvir od ljeta 2014. do ljeta 2016. godine u glavnom, 'sadašnjem' toku radnje, a onda i $\mathrm{u}$ podtoku radnje glavne priče subjekte koji se ostvaruje u nelinearnim analepsama $\mathrm{u}$ vidu fragmenata njenog psihofizičkog odrastanja od najranije dobi sjećanja, i to, prema zapisima, od četvrte (a možda i ranije) do dvadeset i šeste godine njenih života u zbiru njenog jednog života. U tom pogledu Kintsugi tijela narativno spaja dvije ženske odiseje. Jedna je teško i nepredvidljivo putovanje liječenja karcinoma dojke, počevši od slučajnog otkrivanja bolesti u otjelovljenju kvržice kao oblog kamena 'koji se zavukao u gornji dio kupaćeg kostima’ na bočnom rubu desne dojke, kroz liječenje, sve do izlječenja i zdravlja
} 
lest i spasi od smrti. Nije nimalo lako govoriti o smrti, pa ni posredstvom umjetnosti, jer toj temi možemo pristupiti na više načina i sa različitih stajališta, a posebno kada je riječ o individualnom viđenju i razumijevanju smrti. Stoga, u djelu Senke Marić ne možemo govoriti o smrti, nego o procesu umiranja. Iako su ovo dva veoma bliska pojma, umnogome se razlikuju. Smrt označava kraj života, prestanak postojanja, dok je umiranje proces. Možda je najpreciznije kazati da je ovim knjigama prikazan “život u klopci”, kada proces umiranja samo što nije počeo. Ovdje smrt nije stvarna, nego je data kao mogućnost, ali se nastoji pronaći izlaz, i od nje se otrgnuti barem za neko vrijeme, do smrti naredne. U ovom slučaju smrt, odnosno njena blizina, postaje pokretač promjena, što znači da se suočimo, i da se konstantno suočavamo, s vlastitom konačnošću, jer samo tada ništavilo smrti možemo transformirati u autentično iskustvo bivanja.

Lirska subjekta nakon šoka i saznanja da boluje od karcinoma pokušava kontrolirati sebe i svoje emocije, što se ponajbolje očituje u pjesmi "Hronika jedne bolesti" u kojoj je dat opis stanja tijela nakon saznanja o bolesti; zatim se nižu simboli, fragmenti i stihovi o jednom životu. Ta spoznaja i govor o historiji bolesti pokazatelj je, zapravo, da je "tijelo prvo utočište identiteta osobe: posredstvom tijela doživljavamo svijet koji nas okružuje, primamo i procesuiramo informacije iz okoline. Ne dovodeći u pitanje tjelesnim aparatom (perceptivnim sustavom) i umom posredovana znanja i spoznaje, skloni smo potiskivati svijest o tjelesnim osnovama funkcioniranja vlastita identifikacijskog obrasca prilagođavajući ga istovremeno (svjesno ili nesvjesno) kulturalnim okruženjem predstavljenim normama i zahtjevima. Riječ je o dvostruko usmjerenom procesu formiranja identiteta: od tijela kao središta ljudskoga postojanja prema okruženju u kojemu ono postoji i povratno, utjecajima tog istog okruženja natrag prema tijelu samome."13 (Maroš Kiš i Bujina, 2008, str. 111)

tijela, a time i uma i duha žene koja, kojoj i kojom se priča. Ta odiseja počinje nakon nepunih mjesec dana od kada se završava kancerogena, metaforički rečeno, odiseja braka, koja se okončava odlaskom nevjernog supruga glavne junakinje iz njene kuće i porodične zajednice, opet metaforički rečeno, kao otkidanjanjem jedne vrste bolesnog tkiva junakinjinog tijela. (...) Druga narativna odiseja predstavlja zamršeno i, na svoj način, teško probijanje putem iskustva tijelom postajanja i bivanja ženom u mikro svjetovima porodice, mostarskog komšiluka, grada i društva, između ostalih, i u općenitom makro svijetu.” (Raljević, 2019, str. 289-290)

${ }^{13}$ U uvodnom dijelu rada "Tijelo, identitet i diskurs ideologije” Maroš Kiš i Bujina analiziraju odraze ideoloških praksi posredstvom identiteta tijela. Rad donosi rezultate 
I čini se da lirska subjekta suvereno vlada situacijom, suočava se s realnosti, a zatim posmatra vlastitu transformaciju (i psihičku i fizičku) koju uzrokuje saznanje o bolesti i traga za načinom da prihvati takvu sebe. Čini se da je u tome uspjela, ali sve do trenutka kada je poruka rodice istinski približava stvarnosti i kada počinje plakati. I te su suze ovdje prijelaz između života i smrti; njima kao da se proces umiranja zaustavio i usredsređena je "dovući tijelo do starosti" - jednostavno, preživjeti.

Svakako da se tijelom (čak i velikim dijelom) formiraju slike o sebi (i one koje nosimo mi i one na koji nas način posmatra društvo) koje se različito analiziraju. Neke od vidnih promjena na tijelu (čak i iscrpljenost) mogu biti razlog socijalnog odvajanja ili odbacivanja. Izgled nije (barem ne bi trebao biti ili ne bi smio biti!) ono što je najvažnije i što je presudno za odstupanje od identitetskih obrazaca kolektiva. Ovdje nije suočavanje s drugim, ovdje je suočavanje sa sobom i nastojanje da se prihvati drugo ja, ono bolesno, koje počinje da izgrađuje sliku o sebi. Stoga je identitetski obrazac umnogome obilježen iskustvom bolesti i promjenama koje se dešavaju u/na tijelu, kao što lirsku subjektu određuju, odnosno njen svijet okružuju, bol i blizina smrti, jer sve se ovo ne dešava drugom.

Prije par dana dobila sam SMS od rodice iz

Luksemburga:

'Draga Senka, mama mi kaže da si dobro, i da sve

podnosiš kao da se dešava nekom drugom'

Pročitala sam SMS i počela da plačem

(Marić, 2016, str. 12)

Za razliku od poezije, koja za to i ne daje mnogo prostora, u romanu se uspostavljaju dvije radnje i pripovijedanje ide iz sadašnjosti u prošlost,

istraživanja i funkcioniranja tijela i oblikovanja identiteta posredstvom tijela na konkretnom primjeru romana Slavenke Drakulić Frida i načinu na koji se može (ili se teži) izgraditi "idealna slika tijela". Značajan je broj provedenih istraživanja te književnoteorijskih i književnokritičkih tekstova kao rezultata istih u hrvatskoj književnosti koja u fokus stavljaju tijelo (žene) i oblikovanje identiteta posredstvom tijela (njegovih fizičkih karakteristika) na konkretnim primjerima romana savremenih autorica (posebno kod A. Zlatar). To je jasan pokazatelj koliko bosanskohercegovačkoj književnosti nedostaje istraživanja i radova na ovu temu. O romanu Senke Marić Kintsugi tijela se i najviše pisalo, te postoji nekoliko značajnih tekstova, ali ne postoji opsežni književnoteorijski pristupi koji bi bili posvećeni samo temi tijela i identiteta, a koji bi uključivali istraživanje i drugih opusa bh. autorica. 
sabiraju se i prikazuju dijelovi života i porodične situacije. Ovo je roman u kojem je riječ o ženi suočenoj s bolesti, koja čeka operaciju kojom će joj biti odstranjen dio ili dijelovi tijela, te konstantno nastoji da iz te borbe izađe kao pobjednica. U satima, danima i mjesecima koliko traje borba za preživljavanje, ona se vraća u prošlost (dokle joj seže sjećanje) i govori o djevojčici koja je nekada bila, kao i o spoznaji vlastitog tijela (prva menstruacija, masturbacija, upoznavanje drugog tijela), dok je konstantno prisutna rečenica koju je izgovorila kao trinaestogodišnjakinja i koja joj se odrastanjem i sazrijevanjem iznova potvrđuje: “Znaš samo koliko će bolno biti ženom?"'14 (Marić, 2019. str. 38). Protagonistkinja spoznaje sebe i svoje tijelo na dva načina: putem seksualnosti i putem bolesti. Otkriće karcinoma izaziva strah; to nije strah od smrti (njega uopće nema) - posrijedi je strah od neizvjesnosti, strah pred budućnosti, strah od pogleda na djecu, na majku, a onda sve nestaje i prije i poslije operacije ne postoji ništa osim bola i tijela.

Operacija je trajala pet sati. Ti to naravno ne osjetiš. Osjetiš samo bol. Budi te ječanje. Polako postaješ svjesna da si to ti. Tijelo se opire položaju u koji je stavljeno. Nije se u stanju pomaći. Zatočena si u svijetu gdje um ne nalazi put do tijela.

(Marić, 2019, str. 35)

Ovdje je važno kazati da nas bol "kao rijetko koje subjektivno iskustvo pozicionira (zarobljuje) u vlastito tijelo, osamljujući nas u pokušaju da je razumijemo i o njoj komuniciramo."15 (Jurčić Katanur, 2020, str. 585) Bol veoma često proizvodi stanje u kojem čovjek prestaje govoriti, a čuje se samo njegov krik ili vidi grč. Sve bi ostalo na tome da ga Senka Marić nije verbalizovala, "prevela" u književni tekst i na taj način učinila "dostupnim" drugima. Bol je jedinstveno iskustvo, ono što posjeduje samo

\footnotetext{
${ }^{14}$ Ovom rečenicom želi se naglasiti da je odrastanje (pa i cijeli život žene) određeno ili, bolje kazati, obilježeno bolom, kako fizičkom tako i psihičkom. Psihička bol uzrokovana je odrastanjem u disfunkcionalnoj porodici, pored oca alkoholičara, kasnije se javlja njegova bolest i smrt, odlazak supruga, završetak ljubavi; dok se fizička bol manifestira tučom s dječakom koji živi u blizini, preko menstrualne, pa sve do boli uzrokovane karcinomom.

${ }^{15}$ Ovaj je rad izuzetno značajan za temu koju našim radom istražujemo (bolest, tijelo i identitet) jer je predmet istraživanja autorice Cecilije Jurčić Katanur bol. Radom se donosi pregled filozofijskih razmišljanja o fenomenologiji boli, kao i pregled suvremenih naučnih istraživanja o biološki utemeljenoj društvenoj dimenziji boli.
} 
jedna osoba, nositelj tog iskustva; drugima to prenosi posredstvom riječi opisujući jačinu i intenzitet bola koji je uvijek subjektivan, ne objektivan. Nikada ne znamo je li isto ono što osjećam ja, kada je posrijedi bol, s onim što osjeća neko drugi. Tačno je da iskustva bola mogu biti slična, ali nikada ista, i moguće je govoriti jedino o iskustvu vlastitog bola. Senka Marić bol ne zadržava u sebi, ona pravi iskorak i opisima u kojima govori o nepokretnosti tijela i psihičkoj nemoći. Na taj način izlazi iz intimnog u javno i progovara o bolu te ga čini “vidljivim”. Na ovaj način, postavljajući tijelo i bol u fokus, Marić ulazi u drugačiji univerzum i primorava čitatelja da stvarnost posmatra drugim očima. Ova autorica ne opisuje tijelo; preciznije, ona ne piše o tijelu, nego piše tijelo (Hélène Cixous).

Za tekstove u kojima se eksplicitno tematizira tijelo, još ako imaju nešto od autobiografske ispovijesti, Andrea Zlatar navodi da je to "otisak života u tekstu”, jer sve na tijelu (rezovi, izrasline, ožiljci) "jedna su vrsta geografske karte na kojoj su zapisani tragovi naših osobnih povijesti” (Zlatar, 2004, str. 105). Svakako da je tijelo karta na koju je utisnuto naše cjelokupno iskustvo, što pokazuju i dvije knjige Senke Marić. Na ovaj način, i protagonistkinja romana i lirska subjekta preživljavaju vlastitu smrt, ali su i odlučne da žive te da se protiv nje bore; tako one izražavaju svijest o vlastitoj egzistenciji i individualnosti. Upravo zbog toga stvaralaštvo Senke Marić svojim sadržajem čitatelja ostavlja u čudu, nerijetko i bez riječi - jer ovo nije književnica koja se lako da svrstati u bilo kakvu grupu, kružok; ona je svakim stihom i svakom rečenicom jedinstvena i originalna. Književni opus Senke Marić sastoji se od tematizacije ženskog tijela, odnosno njenog suštinskog doživljaja tijela. Ona putem književnosti kazuje kako je teško kontrolirati tijelo, posebno tijelo izloženo bolesti, i na koji način unutarnji i vanjski faktori (doktori, npr.) preuzimaju kontrolu nad njim. U romanu Kintsugi tijela poseban je akcenat na tijelu i promjeni perspektive njegova sagledavanja, od oboljelog tijela do tijela djevojčice. Sve što se događa s nama, odnosno sve što se događa u našem umu ostavlja posljedice koje se manifestiraju na tijelo.

To tijelo se može voljeti. Ti si ga izabrala. I dalje je tijelo žene, kroz sve tvoje preobražaje. Zanosno, lijepo i meko, u samom sebi zaokruženo. Tijelo ratnice. Savršeno isklesano kroz sve poraze, i pobjede. Ožiljci koji ga šaraju su mapa tvog puta. Najistinitija priča o tebi koju ne mogu dokučiti riječi.

(Marić, 2019, str. 118) 
Do smrti naredne i Kintsugi tijela jesu knjige u kojima je ispisano specifično i jedinstveno žensko iskustvo. Otrgnute od smrti, i lirska subjekta i protagonistkinja romana žele svoje iskustvo kazati drugom; to je, na neki način, njihovo oslobađanje (psihičkog) bola, dok je medicina pomogla da se oslobode fizičkog bola. One su svjesne apsurdnosti svijeta, svjesne da se gubi veza s iskonom, s arhajskim - za kojim se vapi kao za prostorom ispunjenja i smiraja, te se posredstvom Riječi neprestano pitaju o samom smislu življenja s bolešću i bolom u svijetu, svijetu bez ljubavi. ${ }^{16}$ Senka Marić zna da je pisanje način da se književnim sredstvima progovori o problemima koji okružuju ženu, jer se jedino pisanjem stvari mogu kazati na izvjestan način.

\section{ZAKLJUČAK}

Za tijelo postoji mnogo definicija, od medicinskih do filozofskih, ali u ovom slučaju, predstavljeno putem umjetnosti, književnosti prvenstveno, mogli bismo kazati da je tijelo dokaz čovjekovog postojanja, jer posredstvom tijela čovjek djeluje u svijetu. I mi funkcioniramo u savršenom skla$\mathrm{du}$ - barem bi taj sklad trebao postojati - tijela i uma. Veoma često tijelo biva potisnuto, zanemareno, jer smo posvećeni samo umu; time ne prihvatamo ni činjenicu da je tijelo dio našeg identiteta, i to ne samo vizuelnog identiteta, nego nas ono umnogome određuje i kroji našu svijest o sebi i uspostavlja odnos prema svijetu. Samo u skladu tijela i uma čovjek može imati unutrašnji mir. A koliko je, sa druge strane, kompleksan i pojam identiteta pokazuju mnogobrojni radovi teoretičara koji identitet promatraju iz različitih perspektiva. Identitet se stvara u procesu razlikovanja, neodbacivanja i neprihvatanja, nego na način uspostavljanja sebe u odnosu na druge. Individualni identitet uvijek se razvija u interakciji s drugima.

Ovim je radom fokus postavljen na tijelo u knjigama Senke Marić Do smrti naredne i Kintsugi tijela. To je tijelo koje i protagonistkinju romana i lirsku subjektu odvaja od ostalih; ono izdvaja njeno ja najprije od nje same, i kao

\footnotetext{
${ }^{16}$ U knjizi Do smrti naredne, drugi ciklus govori o ,umiranju“ ljubavi, o odlasku muškarca, te je u poeziji, detaljnije nego u romanu, opisan završetak ljubavi i odlazak partnera. Središnji dio knjige upravo je fokusiran na tu ,priču“ i zapitanosti ,Zar tako teško je odreći se svih tih sati// što ih u svojoj nesmotrenosti nazvasmo ljubavlju?" Da bi poenta bila u završnici pjesme „Pred prijetnjom smrću“: „Najednom svega je previše// i golog tijela i razbacane odjeće // Zaboraviti treba // Do smrti naredne“.
} 
da se otkida, te ona prestaje biti ono što je bila do trenutka otkrića bolesti. Bolest nas sama po sebi čini različitim od ostalih (zdravih članova društva) koji nemaju iskustvo takve vrste i ne mogu razumjeti osjećaj straha, jer to nije strah od smrti, nego od postepenog gašenja, odumiranja tijela, strah od nemoći, gubitka, odvajanja od djece, majke, prijatelja, ljubavi, ljubavnika. Poezija i roman Senke Marić nam pokazuju da je tijelo osnovni dio vlastitog identiteta čije promjene od spoznaje tijela i sekusualnosi do promjena na tijelu kakve su npr. kvržice na dojci, znatno utiču na njegovo oblikovanje, jer ja bez tijela ne postojim.

To najbolje pokazuje kada u romanu Kintsugi tijela protagonistkinja suočena s bolesti i nakon gubitka dijela tijela (dojki) stoji pred ogledalom uvjeravajući sebe da je lijepa, da je tijelo još uvijek lijepo i tako nastoji vratiti svoje izgubljeno biće, ženu zadovoljnu sobom, ali i ženu koja živi društveni trenutak u kojem je izgled jedan od najvažnijih elemenata današnjeg društva.

Do smrti naredne i Kintsugi tijela Senke Marić su knjige napisane ženskim pismom (iskustvom) i govore o ženskoj poziciji u savremenoj bosanskohercegovačkoj književnosti u kojoj žene postaju - posljednjih desetak godina - sve glasnije, samouvjerenije i hrabrije, kako u suočavanju sa sobom, odnosno u "obračunu" s tzv. tradicionalnim ženskim temama tako i u suočavanju sa svijetom, društvom koje ih okružuje. Potrebno je naglasiti da ove dvije knjige nisu namijenjene samo ženskoj čitalačkoj publici, kako su se dugo vremena unazad predstavljale knjige koje su pisale žene, posebno ako su govorile o vlastitim iskustvima. Bol, gubitak, blizina smrti te ljubav su motivi koji su dominantni u djelu Senke Marić, a ovdje je posrijedi i bolest koja "prijeti” potpunoj promijeni kako tijela tako i duha. U središtu njenog djela je mlada žena koja zbog bolesti nije ostavljena na marginu i osuđena na šutnju i patnju,. Žena je ovdje odlučna da govori i o spoznaji seksualnosti, masturbaciji, menstruaciji, promjenama na tijelu, sve do kvržice na dojci, a zatim slijedi "otkidanje" tijela (doktori odstranjuju prvo jednu, zatim drugu dojku). Ova autorica otvoreno govori o ljepoti ženskog tijela, o želji, o prikrivenoj erotici, ali i o bolesti, jer sve je to tijelo i sve je to žena. Senka Marić je okrenuta sebi, ona posmatra svoj položaju u svijetu. I kao žena i kao književnica s dubokim senzibilitetom zna osjetiti život i pomjeriti sve njegove granice. 


\section{LITERATURA}

Biti, M., 2008. "Virtualnost i materijalnost - sprega ili dihotomija?". Filozofska istraživanja, 2/2008, str. 303-331.

Cixous, H., 2010. “Smijeh Meduze”. U: Ars, 5/6, str. 19-31.

Culler, J., 2001. Književna teorija. Zagreb: AGM.

Grosz, E., 2002. "Preoblikovanje tijela". Treća, časopis Centra za ženske studije, 1/2020, str. 6-26.

Jurčić Katunar, C., 2020. “Jezik boli - između epistemološke asimetrije i biološki zadane društvenosti”. Filozofska istraživanja, 3/2020, str. 585-610.

Kos, S., 2011. "Žena i ideologija(e): Feministička poetika Alexandre Berkove”. Umjetnost riječi, 3-4, str. 221-241.

Lešić, Z., 2006. "Feministička teorija i kritika”. Lešić., Z., Kapidžić Osmanagić, H., Katnić-Bakaršić, M., Kulenović, T. Savremena tumačenja književnosti. Sarajevo: Sarajevo Publishing, str. 420-455.

Lukić, J., 2010. "Žensko pismo i žensko pisanje u devedesetim godinama". Sarajevske sveske, 2/2010. Dostupno na: https://www.sveske.ba/en/content/zent sko-pisanje-i-zensko-pismo-u-devedesetim-godinama sarajevske sveske br. 2 [17. 3. 2021].

Marić, S., 2016. Do smrti naredne. Tešanj: Planjax.

Marić, S., 2019. Kintsugi tijela. Drugo izdanje. Sarajevo - Zagreb: Buybook.

Marić, S., 2019. U dobroj poeziji nema prostora ni za najsitnije greške. Dostupno na: https://mvinfo.hr/clanak/senka-maric-u-dobroj-poeziji-nema-prostoa ra-ni-za-najsitnije-greske [11. 2. 2021].

Marot Kiš, D., Bujan, I., 2008. "Tijelo, identitet i diskurs ideologije”. Fluminensia, 2/2008, str. 109-123.

Moi, T., 2007. Seksualna/tekstualna politika. Zagreb: AGM.

Raljević, S., 2019. "Ženski književni eksperiment Kintsugija tijela Senke Marić”. Kultura, 162, str. 284-305. Dostupno na: http://www.casopiskultura.rs/Maa gazinePublication/Details?magazinePublicationId=3719 [13. 3. 2021].

Zlatar, A., 2004. Tekst, tijelo, trauma. Zagreb: Ljevak. 


\title{
BODY AND IDENTITY IN THE WORKS OF SENKA MARIĆ
}

\begin{abstract}
Summary
Senka Marić, in her book of poetry Do smrti naredne and in her novel Kintsugi tijela, focuses on the body, i.e. the analysis and interpretation of changes in the body caused by illness. The aim of this paper is to confirm the assumption that the body can condition identity and show how this is achieved in the book of poetry Do smrti naredne and the novel Kintsugi tijela, works which best show what kind of change in the body and then female identity we are talking about. These works tell a story about the changes that take place in a woman and the manner that they manifest in the world around her. The changes in the body condition all other "life roles" of a woman and it is the best indicator of (self-)identification. Special attention in the paper is paid to the way the illness affects the body, to what a woman (before and after) is. The body itself is a part of identity and it often physically reflects all the experiences and all the situations that we are exposed to are often visibly manifested on the body, as well as the pain that is impossible to hide and (or) control.
\end{abstract}

Key words: Senka Marić, identity, body, disease, death, poetic self, poetry 